\title{
Aplikasi Berbagai Jenis Pupuk Organik Terhadap Karakter FMA Pada Rhizosfer Tebu Bud Chip
}

\section{Application of Different Organic Fertilizers to FMA Character on Rhizosfer Plantcane Bud Chip}

\author{
Sismita Sari $^{1^{*}}$ dan Wiwik Indrawati ${ }^{2}$ \\ 1,2 Jurusan Tanaman Perkebunan Politeknik Negeri Lampung \\ *E-mail : sismita@polinela.ac.id
}

\begin{abstract}
This study to obtain data on the number and type of FMA. Obtained amount and types of FMA in each treatment of addition of organic fertilizer dosage level. Find out whether the combination of organic fertilizer and the given organic fertilizer dose affect the amount and type of FMA. The experiment design used was Completely Randomized Design 2 Factor and 3 replications. The first factor is 4 types of organic fertilizer $(P)$, namely: Humat acid $(P)$ and cow manure $(D)$, and the second factor is 4 levels of organic fertilizer dose: D0: 0\%, D1: 10 tons of organic fertilizer / ha (50 g per polybag, D2: 20 ton / ha (100 g per polybag), and D3: 30 ton / ha (150 g per polybag) There were 16 experimental units and 3 total replications of 48 experimental unit plots. Myorizas were observed using binocular microscopy and digital camera, observed spores were then grouped by morphological characters including shape, color, and spore ornaments. Identification of indigenous mycorrhizae was done using manual and confirmed by using INVAM website The result of spore count on the application of organic fertilizer containing humic acid, compost fertilizer and the combination of both the highest mycorrhizae is 3,700 in the dosage of humic acid humic fertilizer $50 \mathrm{~g}+100 \mathrm{~g}$ manure. 2,300 spores in organic humic acid $100 \mathrm{~g}+100 \mathrm{~g}$ of fertilizer. The number of spores was moderate, ie 1,541 on humic acid fertilizer $50 \mathrm{~g}+150 \mathrm{~g}$ manure, 1,323 spores at P3D3, 1,203 at treatment of P0D2, and at treatment of P2DO mycorrhiza reached 1.096. The smallest number mycorrhizal spores of 79 spores in the dosage of manure dose $50 \mathrm{~g}$. There are 4 genera of spore that found the most commonly Genus is Glomus and Acaulospora.
\end{abstract}

Keywords: cow dung manure, humic acid, mycorrhiza, sugar cane

Disubmit : 11 Agustus 2018; Diterima: 12 Oktober 2018; Disetujui : 04 Januari 2019;

\section{PENDAHULUAN}

Tebu (Saccharum officinarum L.) adalah satu anggota familia rumput-rumputan (Graminae) Tanaman tebu tumbuh didaerah tropika dan sub tropika sampai batas garis isoterm $20^{\circ} \mathrm{C}$ yaitu antara $190 \mathrm{LU}-350 \mathrm{LS}$. (Indrawanto, 2010). Peningkatan pertumbuhan tanaman bermikoriza lebih nyata pada tanah dengan tingkat kesuburan rendah atau moderat. Kriteria infeksi FMA yang tinggi terjadi pada penambahan dosis $5 \mathrm{~g}$ dan 10 $\mathrm{g}$ dengan persentase sangat tinggi ditunjukan oleh perlakuan dosis $15 \mathrm{~g}$ sebesar $80 \%$. Hal ini diduga karena FMA mampu bekerjasama pada media tanam tanaman SURIAN. Pada perlakuan tanpa inokulasi juga terinfeksi FMA, hal ini menunjukkan bahwa FMA sudah ada pada tanah ultisol dengan penambahan pupuk organic (Zulya, et..al., 2016). Pertanian organik semakin berkembang sejalan dengan timbulnya kesadaran 
akan menjaga kelestarian lingkungan sistem pertanian organik pupuk hayati menjadi salah satu alternatif yang digunakan. Beberapa mikroba tanah seperti Rhizobium, Azespirilium, dan Azotobakter, bakteri pelarut posfat, ektomikoriza, endomikoriza, dan MVA, semua dapat di manfaatkan sebagai biofertilizer dalam pertanian organik. Penggunaan pupuk, asam humat, dan pupuk kompos dari kotoran sapi mengandung senyawa organik berperan penting dalam tanah yaitu sebagai sumber nutrient bagi mikroba, juga dapat menciptakan kondisi fisik dan biokimia tanah sehingga optimal bagi pertumbuhan. Keberadaan senyawasenyawa organik telah terbukti berkorelasi positif terhadap aktivitas enzim mikroba, daya ikat air dan mencegah penguapan pada saat udara kering. Fungi Mikoriza Arbuskula (FMA) merupakan salah satu jenis contoh endomikoriza. Mikoriza merupakan hubungan mutualisme antara cendawan dengan perakaran mikoriza (Rumondang dan Setiadi, 2011). Biofertilizer tersebut fungsinya antara lain untuk membantu penyediaan hara bagi tanaman, membantu penyerapan hara bagi tanaman, membantu dekomposisi bahan organik, menciptakan lingkungan rhizosfer yang baik sehingga akhirnya dapat membantu pertumbuhan dan meningkatkan produksi tanaman. Aplikasi pupuk kandang, kompos dapat meningkatkan kandungan Corganik dan N-total dalam tanah (Zulkarnain, dkk., 2013).

Tujuan penelitian ini adalah mendapatkan: data jumlah dan jenis FMA pada masing-masing perlakuan; jumlah dan jenis-jenis FMA pada masing-masing perlakuan penambahan taraf dosis pupuk organik, dan menganalisis apakah kombinasi 2 jenis pupuk organik dan dosis pupuk organik yang diberikan mempengaruhi jumlah dan jenis FMA.

\section{METODE PENELITIAN}

Penelitian rencana dilakukan selama 6 bulan mulai dari bulan Juli 2017 sampai dengan Desember 2017. Penelitian dilaksanakan di Lahan Praktek Politeknik Negeri Lampung. Alat yang digunakan adalah cangkul, alat penggali, gelas beaker, saringan $600 \mu \mathrm{m}, 74 \mu \mathrm{m}$ dan $45 \mu \mathrm{m}$, dan $35 \mu \mathrm{m}$, cawan petri, pipet, pinset spora, timbangan, termometer, pengaduk, gunting, gelas objek, water bath, cover gelas, sentripuse, mikroskop, dan alat tulis. Bahan yang digunakan adalah sampel tanah, plastik, aquades, label, tissue, glukosa $60 \%$.

Rancangan percobaan yang digunakan adalah Rancangan Acak Lengkap Faktorial (jenis pupuk dan dosis pupuk) faktor pertama adalah 2 Jenis pupuk organik (P) yaitu : asam Humat (P1) dan pupuk kandang sapi (P2), dan Faktor ke dua adalah 4 taraf dosis pupuk organik (D) yaitu: D0: $0 \%$, D1: 10 ton pupuk organic/ ha (50 g per polibag, D2: 20 ton/ha (100 g per polybag), dan D3: 30 ton/ha (150 g per polybag). Terdapat 16 satuan percobaan dan 3 ulangan total 48 petak satuan percobaan. Metode yang digunakan untuk isolasi spora adalah teknik tuang saring dari Pacioni (1992) dan dilanjutkan dengan sentrifugasi dari Brundrett et al (1996). Mikoriza diamati menggunakan mikroskop Binokuler dan camera digital, spora yang teramati kemudian dikelompokkan berdasarkan karakter morfologinya meliputi bentuk, warna, serta ornamen spora. Identifikasi mikoriza indigenous dilakukan dengan menggunakan buku panduan "Working with Mycorrhizas in Forestry and Agriculture" serta dipertegas dengan menggunakan website INVAM. Metode yang digunakan dalam penelitian ini adalah metode deskripsi dengan teknik observasi.

\section{HASIL DAN PEMBAHASAN}

Jumlah Spora. Hasil pengamatan jumlah spora yang diidentifikasi pada rizhosfer tanaman tebu pada berbagai perlakuan dosis pemberian pupuk organik tertera pada Tabel 1.

Pada Tabel 1 jumlah spora mikoriza tertinggi yaitu 3,700 spora, pada rhizosper tanaman tebu dengan pemberian kombinasi pupuk organik asam humat $50 \mathrm{~g}+$ pupuk kandang $100 \mathrm{~g}$. Penggunaan asam humat berpengaruh terhadap penyediaan unsur hara dan perkembangan mikroorganisme tanam seperti MVA dan Rhizobium (Utama and Yahya, 2003). Kombinasi $50 \mathrm{~g}$ asam humat dicampur $150 \mathrm{~g}$ pupuk kandang sapi jumlah spora mencapai 1,541 spora tidak berbeda nyata pada dosis asam humat $150 \mathrm{~g}+$ pupuk kandang 150 g jumlah spora lebih rendah 1,323 spora dan tdk berbeda nyata pada kombinasi P2D0 yaitu dosis pupuk 
kandang $50 \mathrm{~g}$ tanpa asam humat masih tergolong tinggi yaitu 1,203 spora. Jumlah spora juga mencapai 1,096 spora pada penambahan dosis asam humat $50 \mathrm{~g}$ tanpa pupuk kandang. Quilambo (2003), mengemukakan bahwa spora jamur MVA tergolong tinggi jika mencapai 79 - 3,700 spora/ $10 \mathrm{~g}$ tanah kering. Sampel yang diambil dari masing-masing perlakuan $10 \mathrm{~kg}$ kisaran spora tergolong tinggi bahkan dalam $10 \mathrm{~kg}$ tanah jumlah spora tertinggi kisarannya mencapai 3,700 pada kisaran tersebut spora jamur MVA sesuai pendapat Walter masih tergolong tinggi. Jumlah spora tanpa pemberian pupuk organik jumlah spora 634 spora, kondisi tanah kering dan tertekan mempengaruhi jumlah spora pada lahan tanpa pemberian pupuk organik. Sedangkan jumlah spora tergolong sedang pada pemberian pupuk organic asam humat $100 \mathrm{~g}$ dan pupuk kandang $50 \mathrm{~g}$ jumlahnya 323 spora, dosis pupuk kandang $150 \mathrm{~g}$ tanpa asam humat 242 spora, diikuti 170 spora pada pemberian asam humat $150 \mathrm{~g}$ dan pupuk kandang $50 \mathrm{~g}$. 151 spora pada asam humat $100 \mathrm{~g}$ kombinasi pupuk kandang $150 \mathrm{~g}$. Pada campuran asam humat tinggi $150 \mathrm{~g}$ dan tanpa pupuk kandang jumlah spora kecil yaitu 116 spora dan jumlah spora terkecil pada pemberian pupuk kandang $50 \mathrm{~g}$ tanpa asam humat sebesar 79 spora dan 95 spora pada pemberian asam humat yang tinggi $150 \mathrm{~g}$ kombinasi pupuk kandang 100 g. tanaman. Pada penelitian Widyati, (2007) Inokulasi MA secara murni dapat meningkatkan serapan $\mathrm{N}$ tanaman 80\%, P 383\% serta K 51\% dibanding kontrol. Peningkatan serapan hara dengan perlakuan MA murni dapat meningkatkan biomas $91 \%$ dan pertambahan tinggi $114 \%$ dibanding kontrol.

Tabel 1. Jumlah Spora pada masing-masing perlakuan

\begin{tabular}{rr}
\hline Perlakuan & $\begin{array}{r}\text { Jumlah spora } \\
\text { (per 1 kg tanah) }\end{array}$ \\
\hline P0D0 & 634 \\
P0D1 & 79 \\
P0D2 & 1,203 \\
P0D3 & 242 \\
P1D0 & 567 \\
P1D1 & 125 \\
P1D2 & 3,700 \\
P1D3 & 1,541 \\
P2D0 & 1,096 \\
P2D1 & 323 \\
P2D2 & 2,300 \\
P2D3 & 151 \\
P3D0 & 116 \\
P3D1 & 170 \\
P3D2 & 95 \\
P3D3 & 1,323 \\
\hline
\end{tabular}

Keterangan :

P0D0 = Tanpa pupuk organik

P0D1 = Pupuk kandang dosis $50 \mathrm{~g}$

P0D2 = Pupuk kandang dosis $100 \mathrm{~g}$

P0D3 = Pupuk kandang dosis $150 \mathrm{~g}$

P1D0 $=$ Pupuk organik asam humat dosis $50 \mathrm{~g}$

P1D1 = Pupuk organik asam humat dosis $50 \mathrm{~g}+$ pupuk kandang dosis $50 \mathrm{~g}$

P1D2 = Pupuk organik asam humat dosis $50 \mathrm{~g}+$ pupuk kandang dosis $100 \mathrm{~g}$

P1D3 = Pupuk organik asam humat dosis $50 \mathrm{~g}+$ pupuk kandang dosis $150 \mathrm{~g}$

$\mathrm{P} 2 \mathrm{D} 0=$ Pupuk organik asam humat dosis $100 \mathrm{~g}$

P2D1 = Pupuk organik asam humat dosis $100 \mathrm{~g}+$ pupuk kandang dosis $50 \mathrm{~g}$

$\mathrm{P} 2 \mathrm{D} 2=$ Pupuk organik asam humat dosis $100 \mathrm{~g}+$ pupuk kandang dosis $100 \mathrm{~g}$

P2D3 = Pupuk organik asam humat dosis $100 \mathrm{~g}+$ pupuk kandang dosis $150 \mathrm{~g}$ 
P3D0 $=$ Pupuk organik asam humat dosis $150 \mathrm{~g}$

P3D1 = Pupuk organik asam humat dosis $150 \mathrm{~g}+$ pupuk kandang dosis $50 \mathrm{~g}$

$\mathrm{P} 3 \mathrm{D} 2=$ Pupuk organik asam humat dosis $150 \mathrm{~g}+$ pupuk kandang dosis $100 \mathrm{~g}$

$\mathrm{P} 3 \mathrm{D} 3$ = Pupuk organik asam humat dosis $150 \mathrm{~g}+$ pupuk kandang dosis $150 \mathrm{~g}$

Jumlah spora mikoriza berhubungan erat dengan kandungan bahan organik dalam tanah. Keberadaan spora mikoriza dipengaruhi oleh adanya kadar bahan organik. Bahan organik merupakan salah satu komponen yang menunjang dalam meningkatkan kesuburan tanah serta memperbaiki sifat-sifat tanah. Jumlah spora FMA berhubungan erat dengan kandungan bahan organik dalam tanah. Terdapat beberapa tipe spora yaitu Glomus dengan berbagai ragam tipe spora dan Acaulospora lima tipe spora didominasi oleh Glomus hal ini diduga dikarenakan Glomus mempunyai daya adaptasi yang lebih tinggi terhadap kondisi lingkungan dan memiliki spesies yang lebih banyak (Sari, 2017).

Hasil isolasi dan identifikasi spora mikoriza yang diambil dari tanah setiap sample didapatkan hasil bahwa karakteristik spora yang ditemukan mempunyai berbagai perbedaan mulai dari bentuk, warna, maupun ukuran dan terdapat genus, Glomus, Acaulospora, Gigaspora, dan Scutelospora tertera pada Tabel 2.

Tabel 2. Jumlah jenis Spora tiap Genus MVA pada masing-masing perlakuan dosis penambahan pupuk organik

\begin{tabular}{lrrrrr}
\hline & \multicolumn{3}{c}{ Genus } & & \\
\cline { 2 - 6 } Perlakuan & Glomus & Acaulaspora & Gigaspora & Scutelospora & $\begin{array}{c}\text { Total Spora per 10 } \\
\text { kg tanah }\end{array}$ \\
\cline { 2 - 6 } P0D0 & & & 15 & 634 \\
P0D1 & 474 & 72 & 3 & 1 & 54 \\
P0D2 & 45 & 5 & 52 & 2 & 1,203 \\
P0D3 & 1,121 & 8 & 4 & - & 242 \\
P1D0 & 230 & 15 & 10 & 5 & 567 \\
P1D1 & 537 & 3 & 1 & - & 125 \\
P1D2 & 121 & 44 & 184 & 3 & 3,700 \\
P1D3 & 3,469 & 156 & 48 & 24 & 1,541 \\
P2D0 & 1313 & 97 & 383 & 6 & 1096 \\
P2D1 & 610 & 6 & 3 & - & 323 \\
P2D2 & 309 & 64 & 18 & 8 & 2,300 \\
P2D3 & 2,210 & 8 & 24 & 3 & 151 \\
P3D0 & 116 & - & 5 & 3 & 87 \\
P3D1 & 79 & 11 & 12 & - & 95 \\
P3D2 & 147 & 7 & 4 & 2 & 170 \\
P3D3 & 82 & 73 & 60 & 17 & 923 \\
\hline
\end{tabular}

Keterangan :

$\mathrm{POD0}=$ Tanpa pupuk organik

P0D1 = Pupuk kandang dosis $50 \mathrm{~g}$

P0D2 = Pupuk kandang dosis $100 \mathrm{~g}$

P0D3 = Pupuk kandang dosis $150 \mathrm{~g}$

$\mathrm{P} 1 \mathrm{D} 0=$ Pupuk organik asam humat dosis $50 \mathrm{~g}$

$\mathrm{P} 1 \mathrm{D} 1=$ Pupuk organik asam humat dosis $50 \mathrm{~g}+$ pupuk kandang dosis $50 \mathrm{~g}$

$\mathrm{P} 1 \mathrm{D} 2$ = Pupuk organik asam humat dosis $50 \mathrm{~g}+$ pupuk kandang dosis $100 \mathrm{~g}$

P1D3 = Pupuk organik asam humat dosis $50 \mathrm{~g}+$ pupuk kandang dosis $150 \mathrm{~g}$

$\mathrm{P} 2 \mathrm{D} 0=$ Pupuk organik asam humat dosis $100 \mathrm{~g}$

P2D1 = Pupuk organik asam humat dosis $100 \mathrm{~g}+$ pupuk kandang dosis $50 \mathrm{~g}$

P2D2 = Pupuk organik asam humat dosis $100 \mathrm{~g}+$ pupuk kandang dosis $100 \mathrm{~g}$

P2D3 = Pupuk organik asam humat dosis $100 \mathrm{~g}+$ pupuk kandang dosis $150 \mathrm{~g}$ 
Sismita Sari : Aplikasi Berbagai Jenis Pupuk Organik Terhadap Karakter FMA Pada Rhizozfer Tebu ....

$\mathrm{P} 3 \mathrm{D} 0=$ Pupuk organik asam humat dosis $150 \mathrm{~g}$

P3D1 = Pupuk organik asam humat dosis $150 \mathrm{~g}+$ pupuk kandang dosis $50 \mathrm{~g}$

P3D2 = Pupuk organik asam humat dosis $150 \mathrm{~g}$ + pupuk kandang dosis $100 \mathrm{~g}$

P3D3 = Pupuk organik asam humat dosis $150 \mathrm{~g}+$ pupuk kandang dosis $150 \mathrm{~g}$

Hal ini menunjukkan bahwa Glomus mempunyai tingkat adaptasi yang sangat tinggi dibandingkan dengan 3 genus lainnya. Jenis media tanam yang memberikan dan tanaman inang yaitu dapat memberikan respon pertumbuhan positif terhadap tanaman tebu didukung oleh penelitian Rumandang J dan setiadi 2011 pada tanaman jati yang diinokulasikan mikoriza adalah FMA dengan media pasir:tanah yang disterilkan memberikan respon pertumbuhan dan efektifitas inokulasi mikoriza G.aggregatum dan G.manihotis-3. Penggunaan mikoriza sebagai pupuk hayati yang banyak mengandung mikroorganisme akan sangat membantu proses reduksi hara-hara yang terjerap di dalam koloid tanah akibat $\mathrm{pH}$ rendah atau aktifitas $\mathrm{Al}$ dan Fe. Pada jangka waktu yang lama pemberian mikoriza memberikan manfaat yang besar bagi kesuburan tanah (Fitrianto, dkk., 2014).

Tabel 3. Karakterisasi Spora FMA Pada rhizosper tanaman tebu pada berbagai taraf dosis pupuk organik

\begin{tabular}{|c|c|c|c|c|}
\hline \multirow{2}{*}{$\begin{array}{l}\text { Perlakuan } \\
\text { Tanpa pupuk } \\
\text { organik (P0D0) }\end{array}$} & \multicolumn{4}{|c|}{ Genus } \\
\hline & Glomus & Acaulaspora sp & Gigaspora & Skutelospora \\
\hline $\begin{array}{l}\text { Pupuk kandang dosis } \\
50 \mathrm{~g} \text { (P0D1) }\end{array}$ & Glomus & Acaulaspora sp & Gigaspora & Skutelospora \\
\hline $\begin{array}{l}\text { Pupuk kandang dosis } \\
100 \mathrm{~g}(\mathrm{P} 0 \mathrm{D} 2)\end{array}$ & Glomus & Acaulaspora & Gigaspora & Skutelospora \\
\hline $\begin{array}{l}\text { Pupuk kandang dosis } \\
150 \text { g (P0D3) }\end{array}$ & Glomus & Acaulaspora & Gigaspora & Skutelospora \\
\hline
\end{tabular}



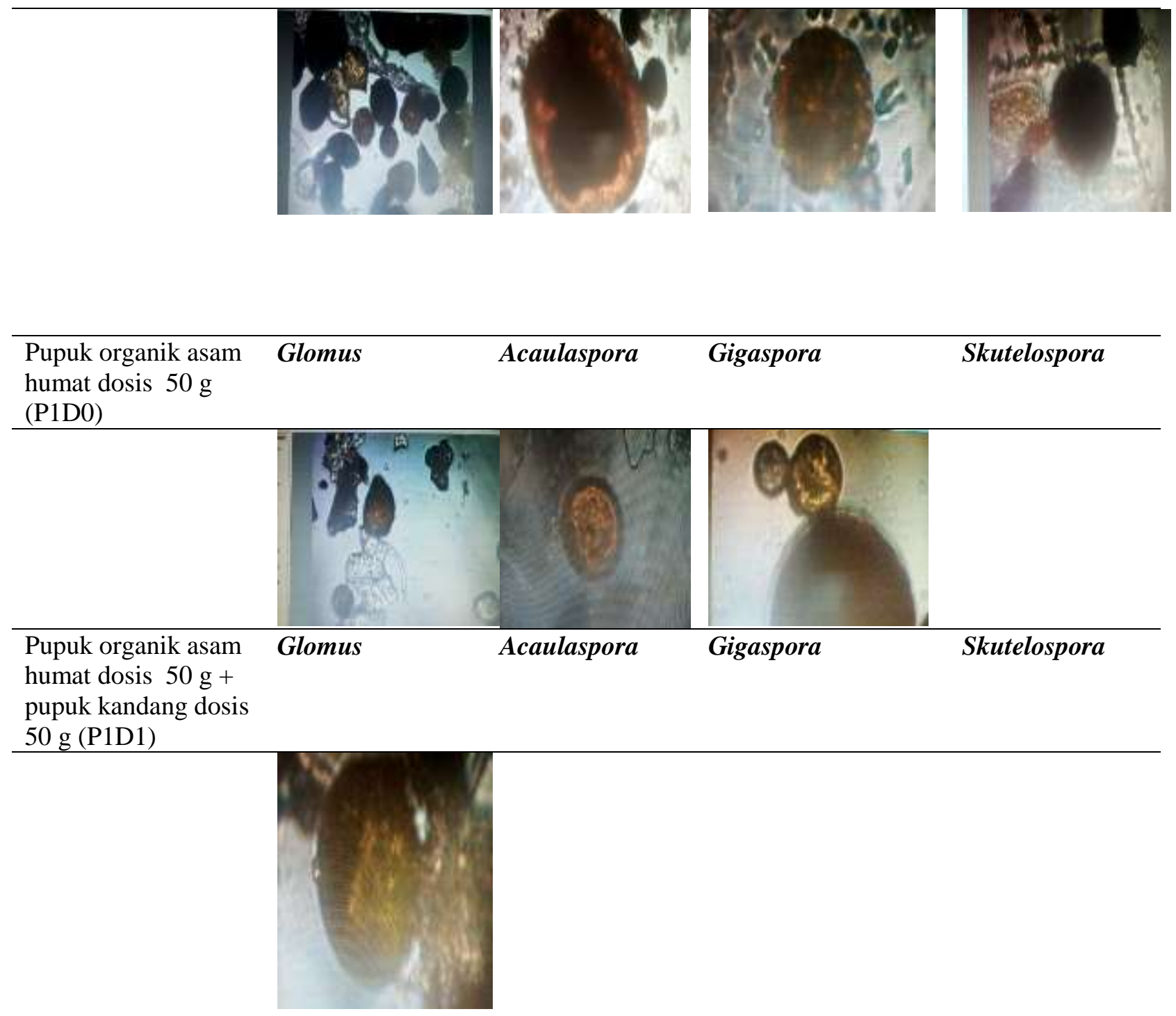

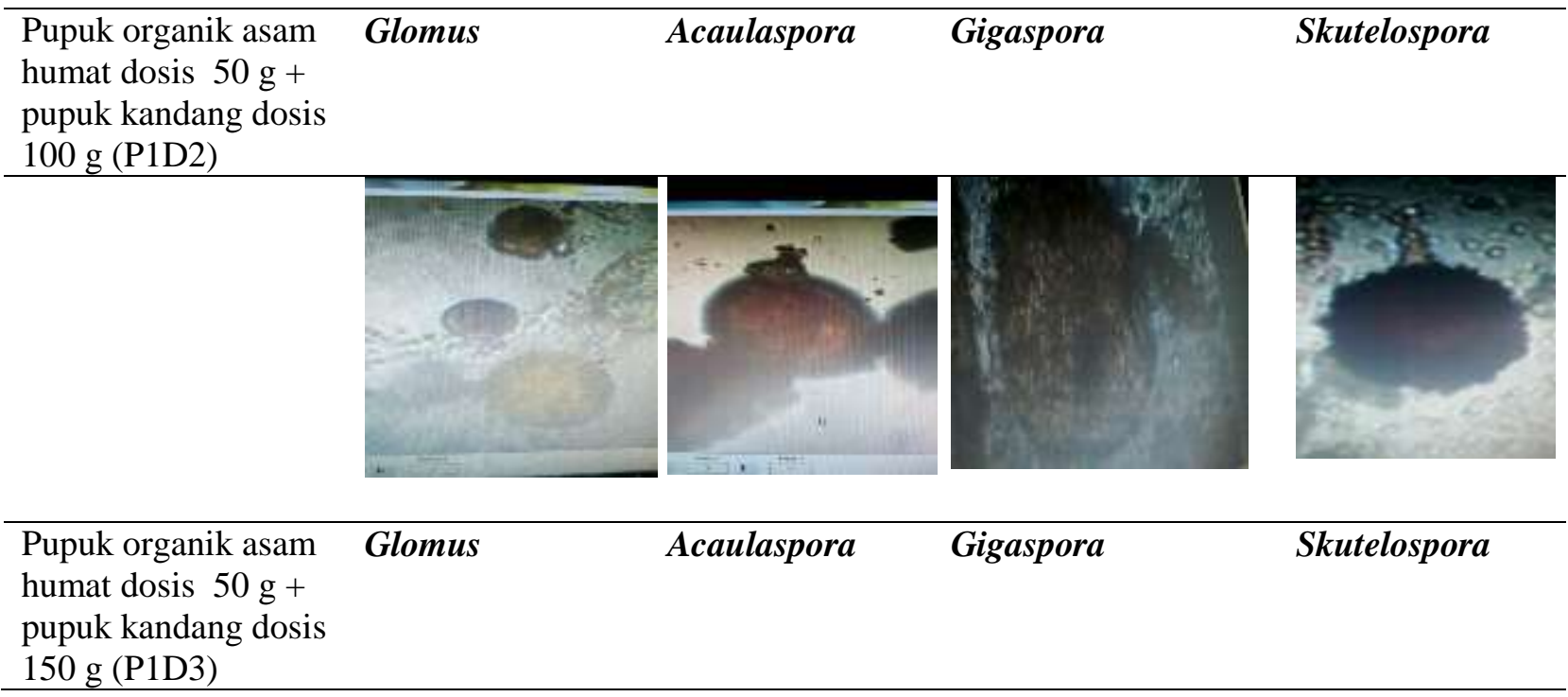


Sismita Sari : Aplikasi Berbagai Jenis Pupuk Organik Terhadap Karakter FMA Pada Rhizozfer Tebu ....
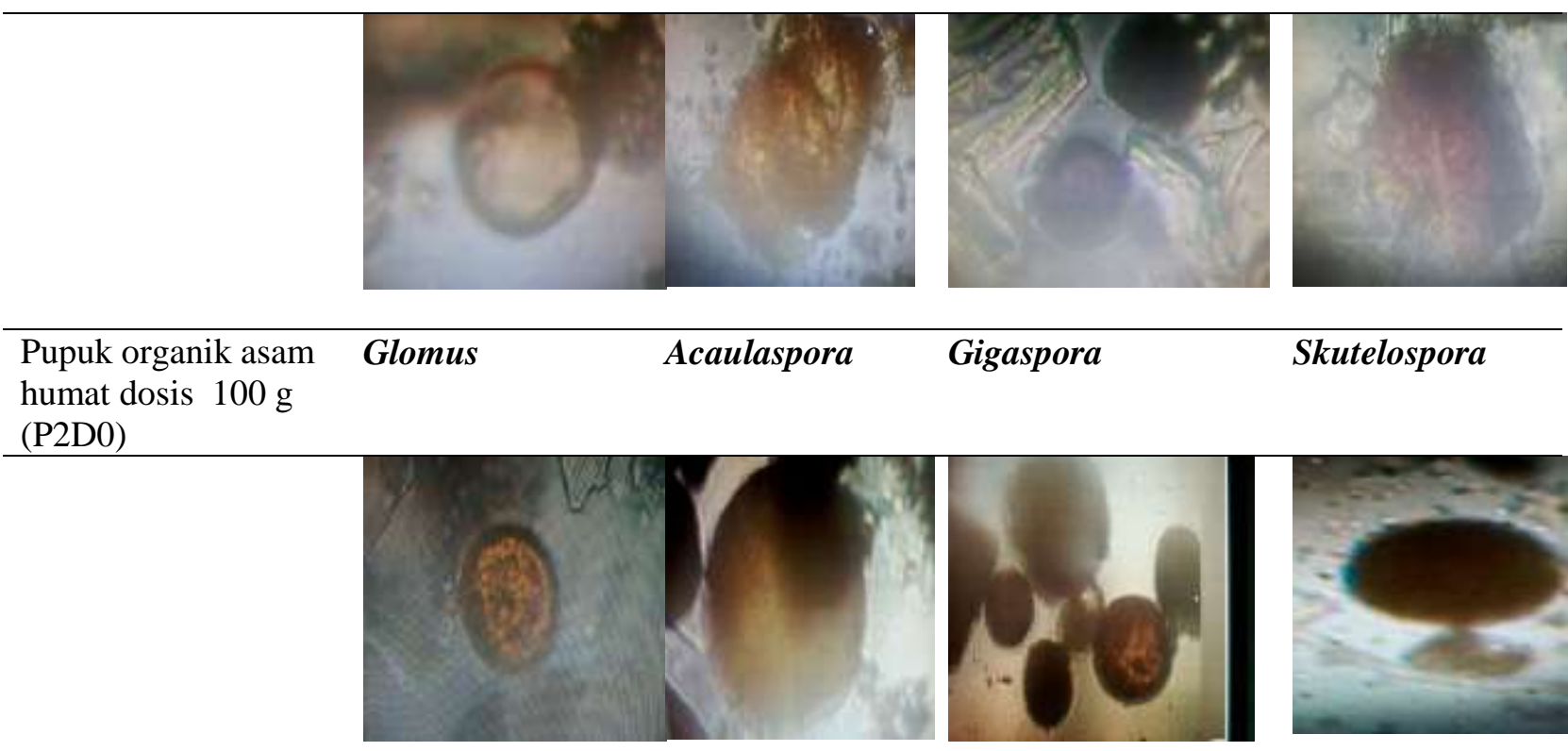

Gigaspora

Skutelospora humat dosis $100 \mathrm{~g}$ (P2D0)
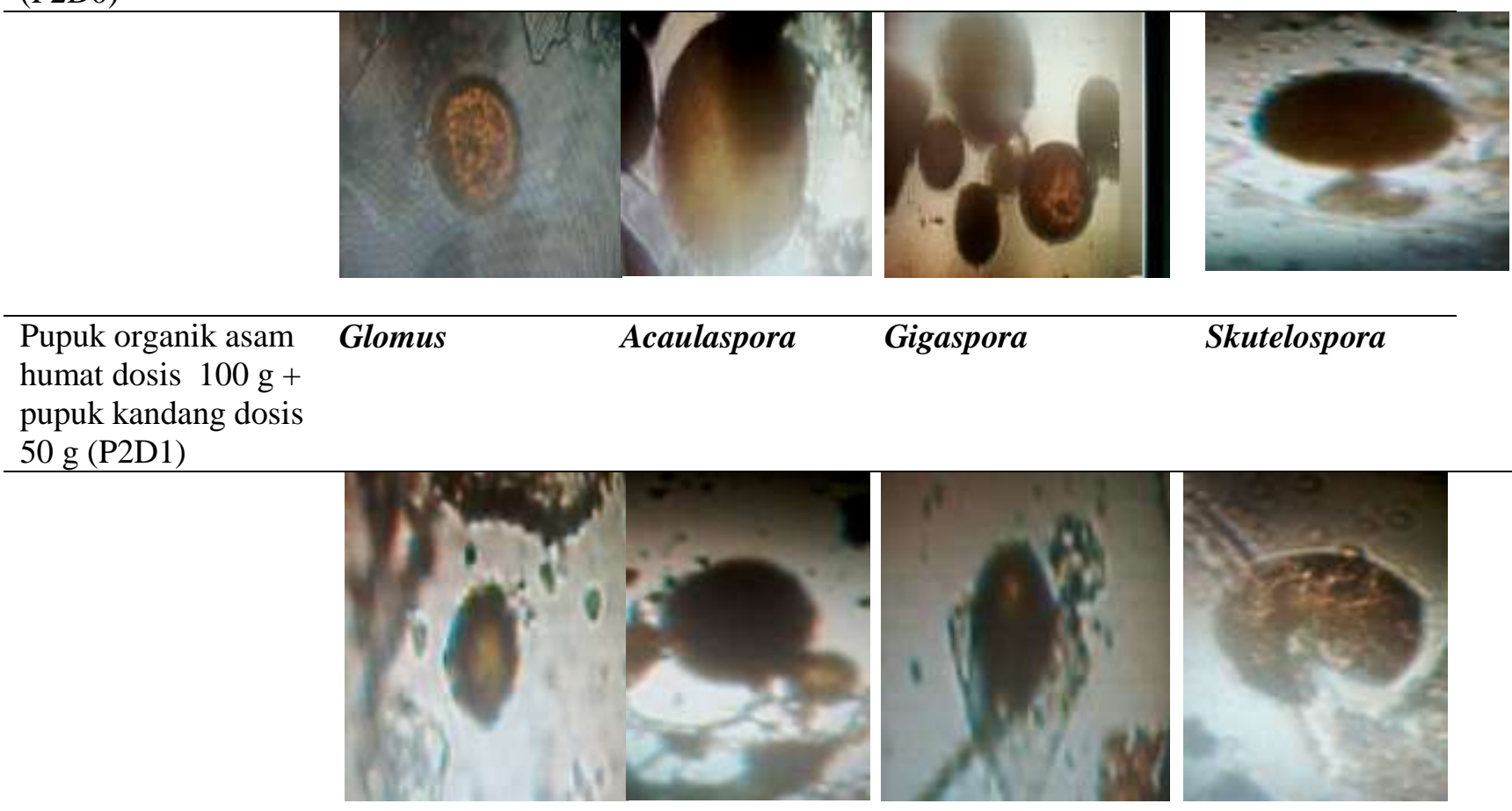

Pupuk organik asam
humat dosis $100 \mathrm{~g}+$
pupuk kandang dosis
$50 \mathrm{~g}$ (P2D1)

Pupuk organik asam
humat dosis $100 \mathrm{~g}+$
pupuk kandang dosis
$100 \mathrm{~g}$ (P2D2)

\section{Glomus}

Acaulaspora

Gigaspora

Skutelospora
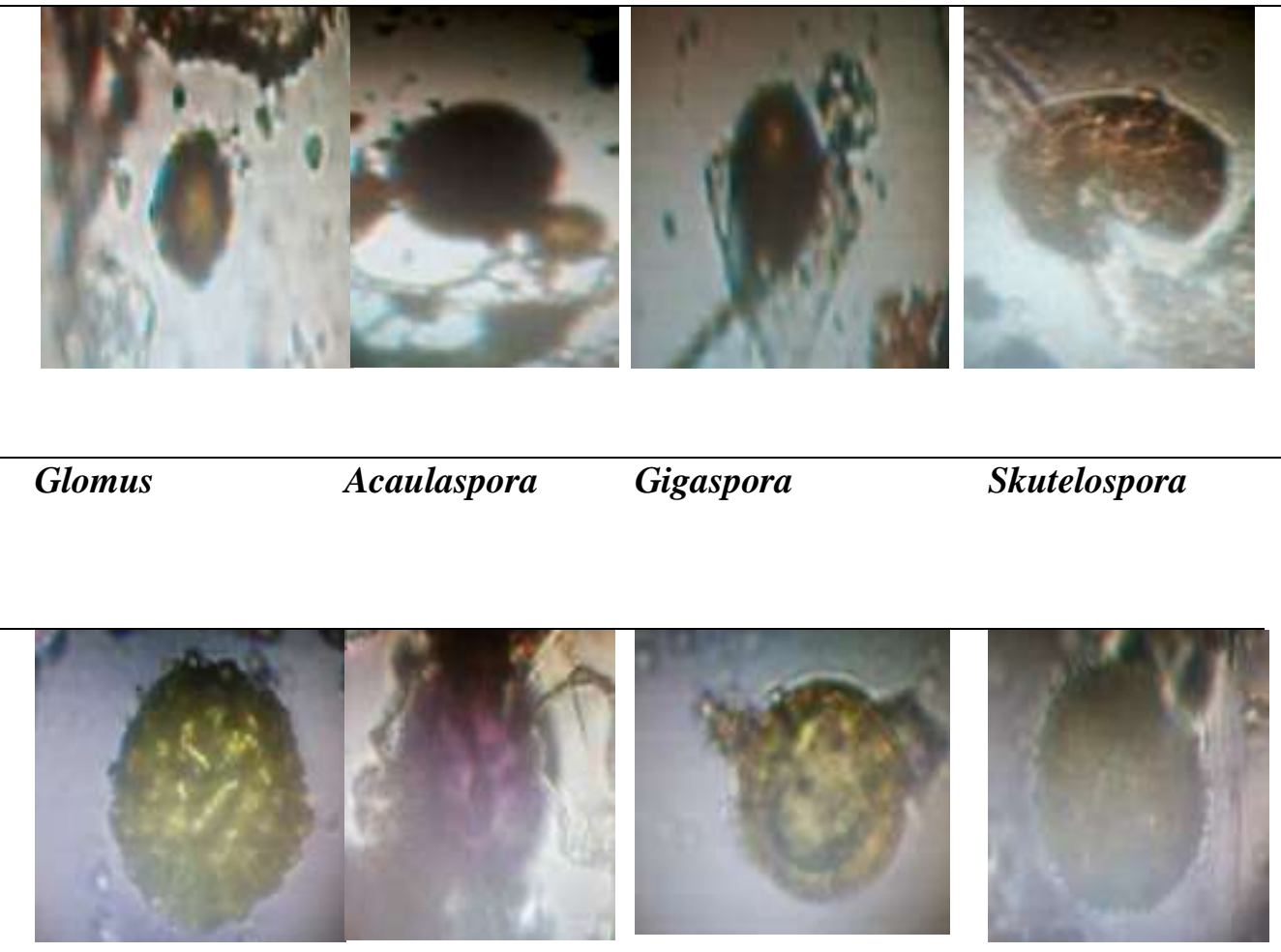

\begin{tabular}{|c|c|c|c|c|}
\hline $\begin{array}{l}\text { Pupuk organik asam } \\
\text { humat dosis } 100 \mathrm{~g}+ \\
\text { pupuk kandang dosis } \\
150 \mathrm{~g}(\mathrm{P} 2 \mathrm{D} 3)\end{array}$ & Glomus & Acaulaspora & Gigaspora & Skutelospora \\
\hline
\end{tabular}



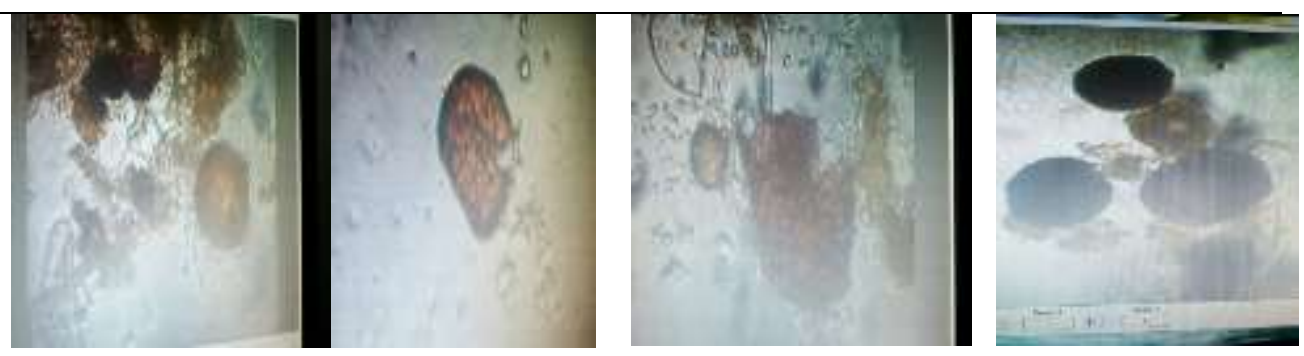

Pupuk organik asam

Glomus

Acaulaspora

Gigaspora

Skutelospora humat dosis $150 \mathrm{~g}$ (P3D0)
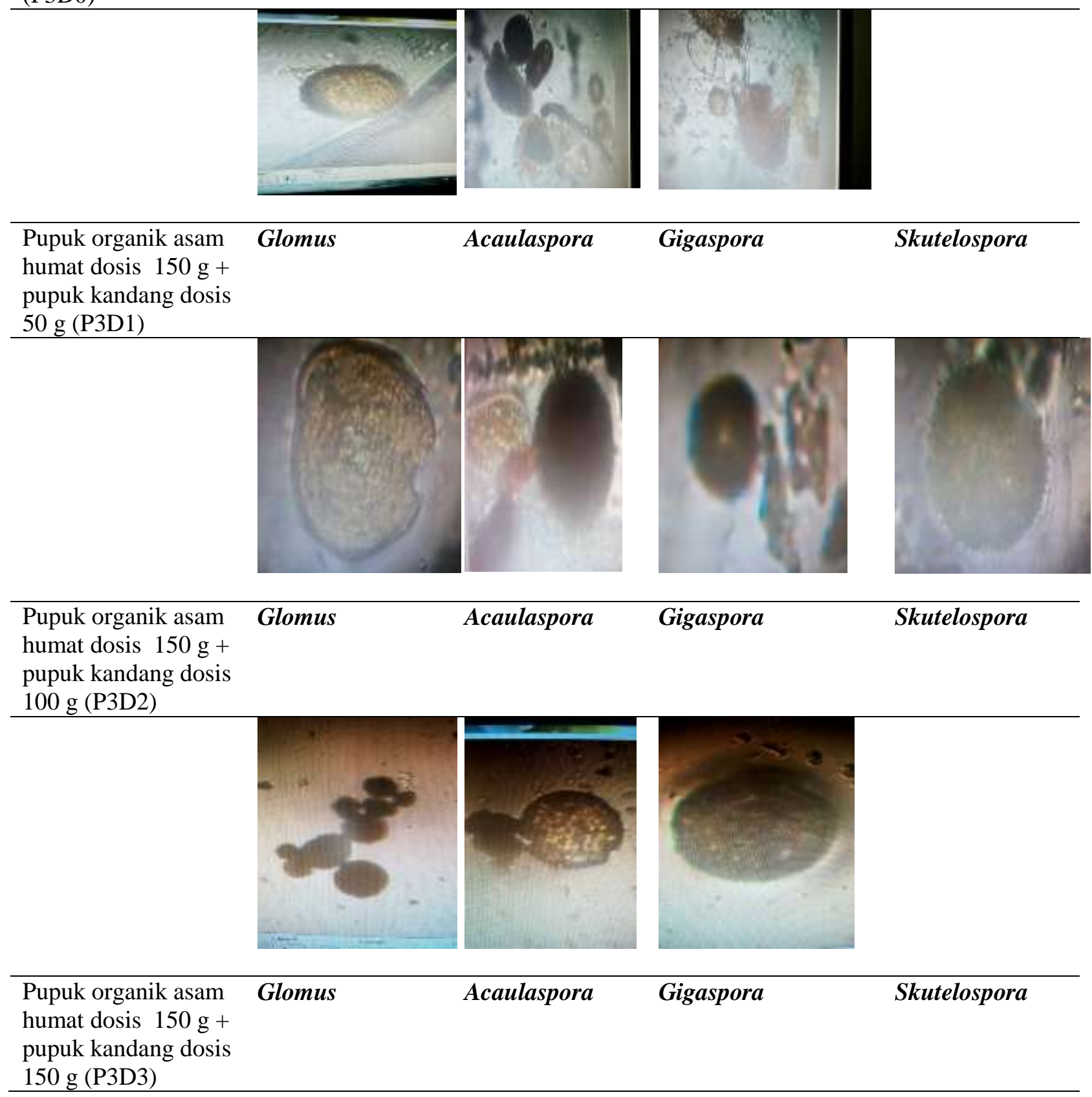

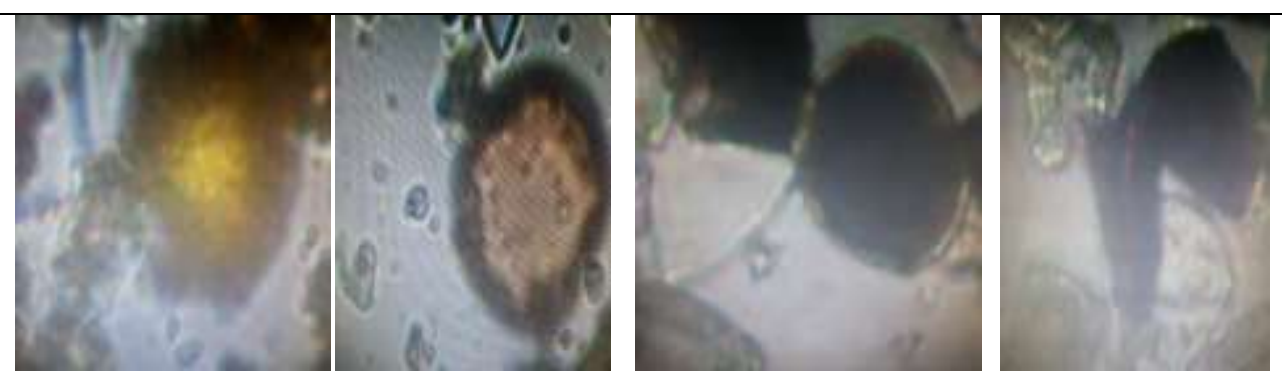

Hasil Tabel 2 dan 3 menunjukkan ada 4 genus jamur MVA yang ditemukan rhizosfer tanaman tebu yaitu Glomus, Acaulospora, Gigaspora, dan Scutelospora. Genus yang paling dominan yaitu pada pemberian asam humat, pupuk kandang, kombinasi pupuk organik asam humat dan pupuk kandang maupun tanpa pemberian pupuk organik didominasi oleh jenis Glomus, diikuti Acaulospora, Gigaspora sp dan Scutellospora sp. Jenis spora yang ditemukan lebih banyak hal ini diduga pada saat penyaringan banyak ditemukan jenis Glomus. Sumiati and O.S Gunawan, (2007), Spesies mikoriza yang berasosiasi pada bawang merah didominasi oleh Glomus sp., hitam dan Gigaspora sp. Keberadaan spora mikoriza dalam tanah sangat dipengaruhi oleh kondisi lingkungan, seperti kondisi fisik dan kimia tanah. Kelangsungan simbiosis antara tanaman dan mikoriza akan berpengaruh terhadap proses-proses metabolisme tanaman dapat mempengaruhi pembentukan akar baru dan meningkatkan permiabilitas membran akar. Banyaknya akar yang baru dengan permiabilitas membran yang tinggi akan menguntungkan bagi proses kolonisasi akar oleh endomikoriza. Selanjutnya dinyatakan pula bahwa akar yang bermikoriza mempunyai kandungan auksin yang lebih tinggi yang memungkinkan peningkatan pertumbuhan akar. Banyaknya jumlah tanah yang mengandung mikoriza akan berpengaruh terhadap pertumbuhan dan perkembangan tanaman (Wahyu, Purwani and Nurhatika, 2013) Hasil penelitian jangka panjang menunjukkan bahwa pemberian pupuk organik, terutama kotoran ayam baik diberikan secara tunggal maupun dikombinasikan dengan pupuk inorganik akan memberbaiki sifat kimia tanah dan sifat biologis tanah. Hasil penelitian Warouw and Kainde P, (2010), menunjukkan bahwa ada 4 genus jamur MVA yang mampu berasosiasi dengan tanaman jati yaitu Glomus, Acaulospora, Gigaspora, dan Sclerocystis, sedangkan tanaman jati dapat berasosiasi lebih dari 1 genus jamur MVA.

\section{KESIMPULAN}

Jumlah spora terhadap pemberian pupuk organic mengandung asam humat, pupuk kompos dan kombinasi keduanya jumlah mikoriza yang paling tinggi adalah 3,700 spora pada dosis pupuk organik asam humat $50 \mathrm{~g}+$ pupuk kandang $100 \mathrm{~g}$. 2,300 spora pada perlakuan pupuk organik asam humat $100 \mathrm{~g}+$ pupuk kiandang $100 \mathrm{~g}$. Jumlah spora tergolong sedang yaitu 1,541 spora pada pemberian pupuk organik asam humat $50 \mathrm{~g}+150 \mathrm{~g}$ pupuk kandang, 1,323 spora pada Pupuk organik asam humat dosis $150 \mathrm{~g}+$ pupuk kandang dosis 150 g. 1,203 spora pada perlakuan Pupuk kandang dosis 100 g, dan pada perlakuan Pupuk organik asam humat dosis $100 \mathrm{~g}$ mikoriza mencapai 1,096 spora. Jumlah spora mikoriza terkecil yaitu 79 spora pada pemberian pupuk kandang dosis $50 \mathrm{~g}$ tanpa campuran.

Terdapat 4 genus spora yang ditemukan pada berbagai macam dosis pupuk organik tunggal dan pemberian pupuk organic campuran genus yang paling banyak yaitu genus Glomus, dan diikuti dengan jumlah genus Acaulospora, Gigaspora, dan Scutelospora. Genus yang paling banyak ditemui adalah Glomus dan Acaulospora. 


\section{DAFTAR PUSTAKA}

Fitrianto, Hermanto and Kriswantoro, H. 2014. Studi Pemanfaatan Mikoriza Arbuskular dan Efisiensi Pupuk Phospat terhadap Pertumbuhan dan Produksi Tanaman Kacang Hijau (Phaseolus radiatus L.) Pada Tanah PMK porsiding Seminar Nasional Lahan Suboptimal, (September), pp. 1-9.

Indrawanto, C. 2010. Budidaya dan Pasca Panen Tebu. ESKA media. doi: 10.3406/arch.1977.1322.

Quilambo, O. A. 2003. The vesicular-arbuscular mycorrhizal symbiosis. Journal of Biotechnology, 2, pp. 539-546. Available at: http://tspace.library.utoronto.ca/handle/1807/1915.

Rumondang, J. and Setiadi, Y. 2011. Evaluasi Aplikasi Fungi Mikoriza Arbuskula (FMA) dan Respon Pertumbuhannya Terhadap Jati (Tectona grandis Linn. F.) di Persemaian. Jurnal Silvikultur Tropika, 2(3), pp. 194-197.

Sari, S. 2017. Identifikasi Fungi Mikoriza Arbuskular ( Fma ) Tanaman Leguminosa Secara Mikroskopis Pada Lahan Olah Tanah Konservasi Musim Tanam Ke 29. Jurnal Penelitian Pertanian Terapan, 17(1), pp. 40-49. doi: 10.25181/jppt.v17i1.39.

Sumiati, E. and O.S Gunawan. 2007. Aplikasi Pupuk Hayati Mikoriza untuk Meningkatkan Efisiensi Serapan Unsur Hara NPK serta Pengaruhnya terhadap Hasil dan Kualitas Umbi Bawang Merah. Journal of horticultura, 17(1), pp. 34-42.

Utama, M. Z. H. and Yahya, S. 2003. Peranan Mikoriza Va, Rhizobium dan Asam Humat pada Pertumbuhan dan Kadar Hara Beberapa Spesies Legum Penutup Tanah. Bul.Agron, pp. 94-99.

Wahyu, E. R., Purwani, K. I. and Nurhatika, S. 2013. Pengaruh Glomus fasciculatum Pada Pertumbuhan Vegetatif Kedelai yang Terinfeksi Sclerotium rolfsii. Jurnal Sains dan Seni Pomits, 2(2), pp. 2337 3520 .

Warouw, V. and Kainde P, R. 2010. Populasi Jamur Mikoriza Vesikular Arbuskular ( Mva ) Pada Zone. eugenia, 16 (April), pp. 38-45.

Widyati, E. 2007. Formulasi Inokulum Mikroba: MA, BPF dan Rhizobium Asal Lahan Bekas Tambang Batubara untuk Bibit Acacia crassicarpa Cunn. Ex-Benth. Biodiversitas, 8(3), pp. 238-241.

Zulkarnain, M., Prasetya, B. and Soemarno. 2013. Pengaruh kompos, pupuk kandang, dan custom-bio terhadap sifat tanah, pertumbuhan dan hasil tebu (Saccharum officinarum L.) pada entisol di kebun Ngrakah-Pawon, Kediri. Indonesian Green Technology Journal, 2(1), pp. 45-52.

Zulya, F., Aneloi, Z. and Meideliza, T. 2016. Inokulasi Beberapa Dosis Fungi Mikoriza Arbuskula. Jurnal Biologi UIN JKT, 9(1), pp. 10-18. 